\title{
Molecular evidence for hybridization between invasive Solidago canadensis and native $S$. virgaurea
}

\author{
Artur Pliszko $10 \cdot$ Joanna Zalewska-Gałosz
}

Received: 10 March 2016/Accepted: 27 June 2016/Published online: 5 July 2016

(C) The Author(s) 2016. This article is published with open access at Springerlink.com

\begin{abstract}
Hybridization between alien and native species is biologically very important and could lead to genetic erosion of native taxa. Solidago $\times$ niederederi was discovered over a century ago in Austria and described by Khek as a natural hybrid between the alien (nowadays regarded also as invasive) $S$. canadensis and native $S$. virgaurea. Although interspecific hybridization in the genus Solidago is considered to be relatively common, hybrid nature of $S . \times$ niederederi has not been independently proven using molecular tools, to date. Because proper identification of the parentage for the hybrid Solidago individuals solely based on morphological features can be misleading, in this paper we report an additive polymorphism pattern expressed in the ITS sequences obtained from individuals representing $S . \times$ niederederi, and confirm the previous hypothesis that the parental species of this hybrid are $S$. canadensis and S. virgaurea. Additionally, based on variability at the cpDNA $r p l 32-t r n \mathrm{~L}$ locus, we showed that in natural populations hybridization occurs in both directions.
\end{abstract}

Keywords Hybrid · Invasive species · ITS, rpl32$\operatorname{trn} \mathrm{L} \cdot$ Sequencing $\cdot$ Solidago $\times$ niederederi

A. Pliszko $(\bowtie) \cdot$ J. Zalewska-Gałosz

Department of Plant Taxonomy, Phytogeography and Herbarium, Institute of Botany, Jagiellonian University, Kopernika Street 31, 31-501 Kraków, Poland

e-mail: artur.pliszko@uj.edu.pl

\section{Introduction}

Solidago canadensis L. (Asteraceae), a North American species, was introduced to Europe as an ornamental plant in the 17th century (Kowarik 2003), and in the 19th and 20th centuries became naturalized in many European countries (Weber 1997). Currently, it is regarded as an invasive species (Kabuce and Priede 2010). Solidago virgaurea L., in its narrow sense (sensu stricto), is a native European species (Slavík 2004; Kiełtyk and Mirek 2014). Spontaneous hybridization between the alien $S$. canadensis and native $S$. virgaurea in Europe was pointed out over a century ago, when Khek (1905) described the hybrid $S . \times$ niederederi Khek from Austria. Since then, $S . \times$ niederederi has been reported from several countries in Europe, including the United Kingdom, Sweden, Denmark, Norway, Germany, Poland, Lithuania and Russia (Nilsson 1976; Burton 1980; Sunding 1989; Mayorov et al. 2012; Pliszko 2013, 2015; Karpavičienė and Radušienè 2016).

Both parental species are morphologically very variable and their taxonomy requires critical revision (Slavík 2004; Semple and Cook 2006; Kiełtyk and Mirek 2014; Semple et al. 2015; Szymura et al. 2015). As a consequence, it is sometimes hard to decide if 'intermediate' morphotypes represent true interspecific hybrids or only the extreme forms of $S$. canadensis or $S$. virgaurea. According to Nilsson (1976), S. × niederederi is usually more or less intermediate between $S$. 
canadensis and S. virgaurea, especially in traits such as leaf shape and venation and size of capitulum. The hybrid can be also characterized by intermediate size of pollen grains and achenes; however, its pollen viability is reduced as well as achene development (Migdałek et al. 2014; Karpavičienè and Radušienė 2016).

Although interspecific hybridization in the genus Solidago is considered to be relatively common (Nesom 1993), proper identification of the parentage for the hybrid individuals solely based on morphological features can be misleading (Schilling et al. 2008). Hybrid nature of $S . \times$ niederederi and its parentage has not been independently proven using molecular tools, to date. In this paper, therefore, we aimed to establish the genetic identity of the parental taxa contributing to the hybrid by means of direct sequencing of chosen DNA regions, namely nuclear ribosomal Internal Transcribed Spacer (ITS) and chloroplast intergenic spacer $r p l 32-t r n \mathrm{~L}$.

\section{Materials and methods}

Plant material and sampling

The study was focused on four taxa of Solidago occurring in Europe, including three alien taxa, $S$. canadensis, $S$. gigantea and $S . \times$ niederederi, and one native species, $S$. virgaurea. Individuals representing each species were morphologically identified based on diagnostic features given by Nilsson (1976); Slavík (2004); Semple and Cook (2006) and Semple et al. (2015). Solidago canadensis was treated in its broad sense (sensu lato), including two varieties recognized in its native range (Semple et al. 2015). DNA was extracted from 15 samples of Solidago: three samples of $S$. $\times$ niederederi, six samples of $S$. canadensis, five samples of $S$. virgaurea and, as a reference, one sample of $S$. gigantea Aiton. All samples were collected in 2014-2015 from distant populations occurring in different areas of Poland. Details of all studied specimens are summarized in Table 1. In each case one individual per population was sampled. Fresh leaves were collected in the field and stored in silica gel. The voucher specimens of molecularly examined individuals of $S . \times$ niederederi were deposited at the Herbarium of the Institute of Botany of the Jagiellonian University in Kraków (KRA 0449366-0449370). To check the potential intraspecific sequence polymorphism, all accessions of the analysed regions for these focal taxa deposited in GenBank were retrieved and included in the analysis (Table 2).

DNA isolation, PCR amplification and direct sequencing

The amount of 10-15 $\mathrm{mg}$ of dried plant material was used for DNA isolation. The plant tissue was ground to fine powder using Mixer Mill 400 (Retsch) and $3 \mathrm{~mm}$ tungsten beads. Total genomic DNA was extracted using the DNeasy Plant Mini Kit (QIAGEN) according to the manufacturer's protocol. The nuclear ribosomal Internal Transcribed Spacer region (including ITS1, 5.8S and ITS2) and the rpl32-trnL intergenic spacer, reported by Shaw et al. (2007) to be highly variable, was amplified in each studied sample. Primers, mix compositions and PCR conditions were as provided by Zalewska-Gałosz et al. (2010). PCR products were purified using the High Pure PCR Product Purification Kit (Roche Diagnostics) according to the manufacturer's protocol and sequenced in two directions using the primers used for amplification. Sequencing was performed using BigDye Terminator v.3.1 (Applied Biosystems) with supplied $5 \times$ sequencing buffer, according to the manufacturer's manual. Sequencing products were purified using the Ethanol/EDTA protocol, resuspended in $12 \mu \mathrm{l}$ formamide and separated on an ABI 3100-Avant Genetic Analyser using $50 \mathrm{~cm}$ capillaries and POP-6 polymer (Applied Biosystems). Raw sequencing profiles were analysed with the DNA Sequencing Analysis Software v.5.1 (Applied Biosystems). The sequences were manually verified/adjusted using the software Finch TV v.1.4.0 (Geospiza Inc.). Alignments of sequences for all regions were conducted manually using BIOEDIT v.5.0.9. (http://www.mbio. ncsu.edu/BioEdit/bioedit. html). Nucleotide polymorphisms were examined with two strands to ensure their consistency and coded using the IUPAC nucleotide ambiguity codes. The GenBank accession numbers for ITS and rpl32-trnL sequences obtained in the study are provided in Table 1.

\section{Results}

Variation of ITS and analysis of the hybrid individuals

ITS sequences obtained from the studied samples were 691-711 base pair long and their alignment covered 
Table 1 Samples of Solidago taxa used in the study, their DNA numbers, GenBank accession numbers and geographical origin

\begin{tabular}{|c|c|c|c|c|c|}
\hline Species & $\begin{array}{l}\text { DNA } \\
\text { sample } \\
\text { no. }\end{array}$ & $\begin{array}{l}\text { GB accession no. } \\
\text { ITS/rpl32-trnL }\end{array}$ & Origin and date of collection & Habitat & $\begin{array}{l}\text { GPS } \\
\text { coordinates }\end{array}$ \\
\hline S. $\times$ niederederi & 346 & $\begin{array}{l}\text { KU872554/ } \\
\text { KU872564 }\end{array}$ & Mieruniszki, NE Poland, 20 Aug 2014 & $\begin{array}{l}\text { Dry roadside } \\
\text { ditch }\end{array}$ & $\begin{array}{l}54^{\circ} 10.784^{\prime} \mathrm{N} \\
22^{\circ} 33.585^{\prime} \mathrm{E}\end{array}$ \\
\hline S. $\times$ niederederi & 347 & $\begin{array}{l}\text { KU872555/ } \\
\text { KU872566 }\end{array}$ & $\begin{array}{l}\text { Ostrowo near Pluszkiejmy, NE Poland, } \\
7 \text { Sep } 2014\end{array}$ & Abandoned field & $\begin{array}{l}54^{\circ} 17.444^{\prime} \mathrm{N} \\
22^{\circ} 27.831^{\prime} \mathrm{E}\end{array}$ \\
\hline S. $\times$ niederederi & 348 & $\begin{array}{l}\text { KU872553/ } \\
\text { KU872565 }\end{array}$ & $\begin{array}{l}\text { Budzów near Jachówka, S Poland, } 30 \\
\text { Sep } 2014\end{array}$ & Abandoned field & $\begin{array}{l}49^{\circ} 45.096^{\prime} \mathrm{N} \\
19^{\circ} 40.636^{\prime} \mathrm{E}\end{array}$ \\
\hline S. canadensis & 1102 & $\begin{array}{l}\text { KU872542/ } \\
\text { KU872557 }\end{array}$ & Bibice, S Poland, 24 Jun 2015 & Abandoned field & $\begin{array}{l}50^{\circ} 06.682^{\prime} \mathrm{N} \\
19^{\circ} 57.626^{\prime} \mathrm{E}\end{array}$ \\
\hline S. canadensis & 1103 & $\begin{array}{l}\text { KU872544/ } \\
\text { KU872556 }\end{array}$ & Białystok, NE Poland, 11 Aug 2015 & Ruderal ground & $\begin{array}{l}53^{\circ} 07.774^{\prime} \mathrm{N} \\
23^{\circ} 08.103^{\prime} \mathrm{E}\end{array}$ \\
\hline S. canadensis & 1150 & $\begin{array}{l}\text { KU872543/ } \\
\text { KU872570 }\end{array}$ & Gołdap, NE Poland, 30 July 2015 & $\begin{array}{c}\text { Former railway } \\
\text { embankment }\end{array}$ & $\begin{array}{r}54^{\circ} 18.832^{\prime} \mathrm{N} \\
22^{\circ} 18.827^{\prime} \mathrm{E}\end{array}$ \\
\hline S. canadensis & 1152 & $\begin{array}{l}\text { KU } 872545 / \\
\text { KU872568 }\end{array}$ & Lubień, S Poland, 8 Sep 2015 & Abandoned field & $\begin{array}{l}49^{\circ} 43.550^{\prime} \mathrm{N} \\
19^{\circ} 59.737^{\prime} \mathrm{E}\end{array}$ \\
\hline S. canadensis & 1153 & $\begin{array}{l}\text { KU872546/ } \\
\text { KU872569 }\end{array}$ & $\begin{array}{l}\text { Warszawa, central Poland, } 29 \text { Sep } \\
2015\end{array}$ & Ruderal ground & $\begin{array}{l}52^{\circ} 13.364^{\prime} \mathrm{N} \\
20^{\circ} 57.871^{\prime} \mathrm{E}\end{array}$ \\
\hline S. canadensis & 1151 & $\begin{array}{l}\text { KU872547/ } \\
\text { KU872567 }\end{array}$ & Jędrzejów, S Poland, 27 Aug 2015 & Abandoned field & $\begin{array}{l}50^{\circ} 37.770^{\prime} \mathrm{N} \\
20^{\circ} 16.856^{\prime} \mathrm{E}\end{array}$ \\
\hline S. gigantea & 1101 & $\begin{array}{l}\text { KU872541/ } \\
\text { KU872558 }\end{array}$ & $\begin{array}{l}\text { Węgrzce near Kraków, S Poland, } 24 \\
\text { Jun } 2015\end{array}$ & Roadside verge & $\begin{array}{r}50^{\circ} 06.537^{\prime} \mathrm{N} \\
19^{\circ} 57.922^{\prime} \mathrm{E}\end{array}$ \\
\hline S. virgaurea & 1104 & $\begin{array}{l}\text { KU872548/ } \\
\text { KU872559 }\end{array}$ & Rutka-Tartak, NE Poland, 4 Aug 2015 & Roadside slope & $\begin{array}{l}54^{\circ} 19.753^{\prime} \mathrm{N} \\
22^{\circ} 57.583^{\prime} \mathrm{E}\end{array}$ \\
\hline S. virgaurea & 1146 & $\begin{array}{l}\text { KU872549/ } \\
\text { KU872560 }\end{array}$ & $\begin{array}{l}\text { Filipów Trzeci, NE Poland, } 16 \text { Aug } \\
2015\end{array}$ & Abandoned field & $\begin{array}{l}54^{\circ} 09.543^{\prime} \mathrm{N} \\
22^{\circ} 37.570^{\prime} \mathrm{E}\end{array}$ \\
\hline S. virgaurea & 1147 & $\begin{array}{l}\text { KU872551/ } \\
\text { KU872561 }\end{array}$ & Żelazki, NE Poland, 12 Aug 2015 & Abandoned field & $\begin{array}{l}54^{\circ} 13.617^{\prime} \mathrm{N} \\
22^{\circ} 27.534^{\prime} \mathrm{E}\end{array}$ \\
\hline S. virgaurea & 1148 & $\begin{array}{l}\text { KU872552/ } \\
\text { KU872562 }\end{array}$ & Połaniec, S Poland, 23 Aug 2015 & Abandoned field & $\begin{array}{l}50^{\circ} 25.585^{\prime} \mathrm{N} \\
21^{\circ} 16.022^{\prime} \mathrm{E}\end{array}$ \\
\hline S. virgaurea & 1149 & $\begin{array}{l}\text { KU872550/ } \\
\text { KU872563 }\end{array}$ & Alwernia, S Poland, 17 Sep 2015 & Abandoned field & $\begin{array}{l}50^{\circ} 04.602^{\prime} \mathrm{N} \\
19^{\circ} 33.379^{\prime} \mathrm{E}\end{array}$ \\
\hline
\end{tabular}

$672 \mathrm{bp}$. Ten polymorphisms were detected in the data set (Table 2). All samples of Solidago virgaurea had identical sequences and did not have any intraindividual polymorphism. The ITS sequence of this species was the most divergent and was clearly differentiated from $S$. canadensis and/or S. gigantea by eight single nucleotide polymorphism sites (Table 2). Within samples of $S$. gigantea and $S$. canadensis sensu lato intra-individual polymorphism was detected at three positions of the alignment (249, 330 and 509). At position 330, more than half of the studied samples of $S$. canadensis, $S$. gigantea and $S$. $\times$ niederederi showed a sequence ambiguity what suggests the presence of paralogs within the genomes studied. Incomplete homogenization at this site, however, does not influence the clear inference of the hybrid nature of $S . \times$ niederederi, which is possible based on remaining polymorphic sites. Only one, taxonomically specific position (465) allowed to distinguish between $S$. gigantea and $S$. canadensis.

All three accessions of the hybrid $S . \times$ niederederi showed heterozygosity at seven positions, all diagnostic and pointed to $S$. virgaurea as one of the parental species. The second parent was detected based on the polymorphism expressed at position 465 at the alignment - the only one position that distinguished $S$. canadensis and $S$. gigantea. At this position, the hybrid samples possessed C while $S$. 
Table 2 Polymorphism in the ITS sequences from the Solidago taxa and the hybrid individuals of $S$. $\times$ niederederi

\begin{tabular}{|c|c|c|c|c|c|c|c|c|c|c|c|}
\hline \multirow[t]{2}{*}{ Taxon } & \multirow[t]{2}{*}{ GB accession no. } & \multicolumn{10}{|c|}{ Position in the alignment } \\
\hline & & 249 & 330 & 385 & 432 & 465 & 509 & 550 & 606 & 607 & 608 \\
\hline S. gigantea & HQ142592, HQ142593, DQ005980, KU872541 & $\mathrm{T}$ & G & $\mathrm{C}$ & $\mathrm{C}$ & $\mathrm{T}$ & $\mathrm{C}$ & $\mathrm{G}$ & G & $\mathrm{T}$ & G \\
\hline S. gigantea & HQ142594, HQ142595, EU125362, KP153086 & . & $\mathrm{R}$ & . & . & . & $\mathrm{T}$ & . & . & . & . \\
\hline S. canadensis & $\begin{array}{l}\text { FJ859719, EU125361, AF477665, KU872544, } \\
\text { KU872545, KU872546, KU872551, KU872543 }\end{array}$ & $\mathrm{T}$ & $\mathrm{R}$ & $\mathrm{C}$ & $\mathrm{C}$ & $\mathrm{C}$ & $\mathrm{T}$ & $\mathrm{G}$ & G & $\mathrm{T}$ & G \\
\hline S. canadensis & KU872542 & . & G & . & . & . & . & . & . & . & . \\
\hline $\begin{array}{l}\text { S. canadensis } \\
\text { var. scabra }\end{array}$ & HQ142590 & . & G & . & . & . & . & . & . & . & . \\
\hline $\begin{array}{l}\text { S. canadensis } \\
\text { var. scabra }\end{array}$ & U97646 & $\mathrm{C}$ & . & . & . & . & . & . & . & . & . \\
\hline S. virgaurea & EU125358, KU872548-52 & $\mathrm{T}$ & G & $\mathrm{T}$ & A & $\mathrm{C}$ & $\mathrm{C}$ & A & $\mathrm{T}$ & $\mathrm{C}$ & A \\
\hline S. $\times$ niederederi & KU872553, KU872554 & $\mathrm{T}$ & $\mathrm{R}$ & $\mathrm{Y}$ & M & $\mathrm{C}$ & $\mathrm{Y}$ & $\mathrm{R}$ & $\mathrm{K}$ & $\mathrm{Y}$ & $\mathrm{R}$ \\
\hline S. $\times$ niederederi & KU872555 & . & $\mathrm{G}$ & . & . & . & . & . & . & . & . \\
\hline
\end{tabular}

Polymorphic nucleotide sites are coded using the IUPAC code

Dots refer to the identical nucleotides provided above for each species

GB accession numbers of the samples collected for the purpose of this study are evidenced in Table 1

gigantea had $\mathrm{T}$, similar to $S$. virgaurea and $S$. canadensis. Considering above, the second parent of the hybrid $S . \times$ niederederi was proved to be $S$. canadensis.

Variation of $c p$ DNA region and identification of the maternal species

The sequences of the rpl32-trn $\mathrm{L}$ intergenic spacer were 695-732 base pair long and their alignment counted $732 \mathrm{bp}$. The data set was only weakly polymorphic, with three polymorphisms detected: one, 30 to 37-bp long insertion/deletion (indel), at position 256-292 and two single nucleotide polymorphisms at positions 177 and 426 of the alignment (Table 3). The long insertion/deletion clearly distinguished Solidago virgaurea while the other species, namely $S$. canadensis and $S$. gigantea, cannot be differentiated based on the rpl32-trnL sequence. Moreover, S. canadensis expressed inter-individual polymorphism in this region. Accessions KU872556, KU872567, KU872569 and KU872570 had C at position 426 of the alignment while accessions KU872557 and KU872568 had $\mathrm{T}$ at this position. The rpl32-trn L sequence obtained from the studied hybrid individuals was not identical. On the basis of detected polymorphism, it can be stated that the hybrid individual collected in Mieruniszki (accession KU872564) inherited cpDNA from $S$. virgaurea, while the individual collected in Budzów near Jachówka (accession KU872565) had cpDNA haplotype alike $S$. canadensis (accessions KU872557 and KU872568). The last hybrid individual collected in Ostrowo near Pluszkiejmy had identical rpl32-trnL sequence as S. canadensis (accessions KU872556, KU872567, KU872569, KU872570) and S. gigantea (accession KU872558). Solidago gigantea, however, was excluded from the parentage of $S . \times$ niederederi based on ITS polymorphism.

Based on the examination of the rpl32-trn $\mathrm{L}$ sequence, it can be concluded that hybridization occurs in both directions with maternal inheritance of a specific plastid genome from $S$. virgaurea and $S$. canadensis.

\section{Discussion}

In this paper we test the molecular character of Solidago $\times$ niederederi from three distant populations occurring in Poland. We show that the hybrid individuals retained both copies of ITS sequences inherited from their parental species, $S$. virgaurea and $S$. canadensis. This finding confirmed the hybrid 
Table 3 Sequence variation in the rpl32-trnL chloroplast intergenic spacer in the Solidago species and the hybrid individuals of S. $\times$ niederederi

\begin{tabular}{|c|c|c|c|c|}
\hline \multirow[t]{2}{*}{ Taxon } & \multirow[t]{2}{*}{ GB accession no. } & \multicolumn{3}{|c|}{ Position in the alignment } \\
\hline & & 177 & $256-292$ & 426 \\
\hline S. gigantea & KU872558 & $\mathrm{C}$ & - & $\mathrm{C}$ \\
\hline S. canadensis & $\begin{array}{l}\text { KU872556, KU872567, KU872569, } \\
\text { KU872570 }\end{array}$ & $\mathrm{C}$ & - & $\mathrm{C}$ \\
\hline S. canadensis & KU872557, KU872568 & $\mathrm{C}$ & - & $\mathrm{T}$ \\
\hline S. virgaurea & KU872559 & A & ATGTCTAAAAGAATAATTCTTGTATTTTCT & $\mathrm{C}$ \\
\hline S. virgaurea & KU872560-63 & $\mathrm{C}$ & ATGTCTAAAAGAATAATTCTTGTATTTTCTGAATTCT & $\mathrm{C}$ \\
\hline S. $\times$ niederederi & KU872566 & $\mathrm{C}$ & - & $\mathrm{C}$ \\
\hline S. $\times$ niederederi & KU872565 & $\mathrm{C}$ & - & $\mathrm{T}$ \\
\hline S. $\times$ niederederi & KU872564 & $\mathrm{C}$ & ATGTCTAAAAGAATAATTCTTGTATTTTCTGAATTCT & $\mathrm{C}$ \\
\hline
\end{tabular}

All samples are evidenced in Table 1

origin of $S . \times$ niederederi as well as its parentage originally proposed by Khek (1905). Although $n r$ DNA genes undergo concerted evolution relatively quickly (e.g., Fuertes Aguilar et al. 1999), additive polymorphism pattern detected in the ITS region has been successfully used in the previous studies on interspecific hybridization in many different genera of plants (e.g., Soltis et al. 1995; Zalewska-Gałosz and Ronikier 2012; Zalewska-Gałosz et al. 2014; Bobrov et al. 2015). A lack of any signs of recombination or homogenization between both parental ITS ribotypes may suggest relatively recent forming of hybrid individuals and/or lack of generative propagation. On the other hand, relatively easy formation of hybrid individuals (both directions of crossing evidenced in this study) and some viability of pollen detected in S. $\times$ niederederi (Migdałek et al. 2014) could be a prerequisite for possible existence of gene flow between parental species through the hybrid individuals as a genetic 'bridge'. This can be especially evolutionary important because $S$. $\times$ niederederi is an example of spontaneous interspecific hybrid between an invasive and a native species. Such hybridization, together with introgression, competitive exclusion and niche displacement are pointed out as specific pathways in which invasive species may be altering the evolutionary history of native species (Vilà et al. 2000; Guo 2014). The knowledge of hybrid fertility in $S . \times$ niederederi as well as possible introgression between $S$. canadensis and $S$. virgaurea is still lacking. It cannot be excluded that $S$. $\times$ niederederi could form advanced recombinant generations of hybrids
$\left(\mathrm{F}_{2}, \mathrm{~F}_{3} \ldots\right.$ etc. $)$ or backcrosses with the parental species. Because a direct loss of genetic distinctiveness via genetic erosion is possible, areas where $S$. virgaurea is rare or occurs in isolated populations should be protected against the invasion of S. canadensis.

Acknowledgments The study was financially supported by the Jagiellonian University in Kraków (DS/MND/WBiNoZ/IB/ 2/2015).

Open Access This article is distributed under the terms of the Creative Commons Attribution 4.0 International License (http:// creativecommons.org/licenses/by/4.0/), which permits unrestricted use, distribution, and reproduction in any medium, provided you give appropriate credit to the original author(s) and the source, provide a link to the Creative Commons license, and indicate if changes were made.

\section{References}

Bobrov AA, Zalewska-Gałosz J, Jopek M, Movergoz EA (2015) Ranunculus schmalhausenii (section Batrachium, Ranunculaceae), a neglected water crowfoot endemic to Fennoscandia - a case of rapid hybrid speciation in postglacial environment of North Europe. Phytotaxa 233:101-138. doi:10.11646/phytotaxa.233.2.1

Burton R (1980) Solidago $\times$ niederederi Khek in Britain. Watsonia 13:123-124

Fuertes Aguilar J, Rossello JA, Nieto Feliner G (1999) Nuclear ribosomal DNA (nrDNA) concerted evolution in natural and artificial hybrids of Armeria (Plumbaginaceae). Mol Ecol 8:1341-1346. doi:10.1046/j.1365-294X.1999.00690.x

Guo QF (2014) Plant hybridization: the role of human disturbance and biological invasion. Diversity Distrib 20:1345-1354. doi:10.1111/ddi.12245 
Kabuce N, Priede A (2010) NOBANIS-Invasive alien species fact sheet-Solidago canadensis. Online database of the north European and baltic network on invasive alien species-NOBANIS www.nobanis.org

Karpavičienè B, Radušiené J (2016) Morphological and anatomical characterization of Solidago $\times$ niederederi and other sympatric Solidago species. Weed Sci 64:61-70. doi:10.1614/WS-D-15-00066.1

Khek E (1905) Floristisches aus Ober-Oesterreich. Allg Bot Z Syst 11:21-23

Kiełtyk P, Mirek Z (2014) Taxonomy of the Solidago virgaurea group (Asteraceae) in Poland, with special reference to variability along an altitudinal gradient. Folia Geobot 49:259-282. doi:10.1007/s12224-013-9180-2

Kowarik I (2003) Biologische invasionen: neophyten und neozoen in mitteleuropa. Ulmer, Stuttgart

Mayorov SR, Bochkin VD, Nasimovich YuA, Shcherbakov AV (2012) Adventivnaya flora Moskvy i Moskovskoi oblastii. KMK, Moscow

Migdałek G, Kolczyk J, Pliszko A, Kościńska-Pająk M, Słomka A (2014) Reduced pollen viability and achene development in Solidago $\times$ niederederi Khek from Poland. Acta Soc Bot Pol 83:251-255. doi:10.5586/asbp.2014.025

Nesom GL (1993) Taxonomic infrastructure of Solidago and Oligoneuron (Asteraceae: Astereae) and observations on their phylogenetic position. Phytologia 75:1-44

Nilsson A (1976) Spontana gullrishybrider (Solidago canadensis $\times$ virgaurea $)$ i Sverige och Danmark. Sven Bot Tidskr 70:7-16

Pliszko A (2013) A new locality of Solidago $\times$ niederederi Khek (Asteraceae) in Poland. Biodiv Res Conserv 29:57-62. doi:10.2478/biorc-2013-0008

Pliszko A (2015) Neotypification of Solidago $\times$ niederederi (Asteraceae). Phytotaxa 230:297-298. doi:10.11646/ phytotaxa.230.3.10

Schilling EE, Beck JB, Calie PJ, Small RL (2008) Molecular analysis of Solidaster cv. Lemore, a hybrid goldenrod (Asteraceae). J Bot Res Inst Texas 2:7-18

Semple J, Cook R (2006) Solidago Linnaeus. In: Flora of North America Committee (eds) Flora of North America. Oxford University Press, Oxford, pp 107-166

Semple JC, Rahman H, Bzovski S, Sorour MK, Kornobis K, Lopez Laphitz R, Tong L (2015) A multivariate morphometric study of the Solidago altissima complex and S. canadensis (Asteraceae: Astereae). Phytoneuron $10: 1-31$

Shaw J, Lickey EB, Schilling EE, Small RL (2007) Comparison of whole chloroplast genome sequences to choose noncoding regions for phylogenetic studies in Angiosperms: the tortoise and the hare III. Am J Bot 94:275-288

Slavík B (2004) Solidago L. - zlotobýl. In: Slavík B, Štěpánková J (eds) Květena České Republiky 7. Academia, Praha, pp 114-123

Soltis PS, Plunkett GM, Novak SJ, Soltis DE (1995) Genetic variation in Tragopogon species: additional origins of the allotetraploids T. mirus and T. miscellus (Compositae). Am J Bot 82:1329-1341

Sunding P (1989) Naturaliserte Solidago-(gullris-) arter i Norge. Blyttia 47:23-27

Szymura M, Szymura TH, Kreitschitz A (2015) Morphological and cytological diversity of goldenrods (Solidago L. and Euthamia Nutt.) from south-western Poland. Biodiv Res Conserv 38:41-49. doi:10.1515/biorc-2015-0010

Vilà M, Weber E, D'Antonio CM (2000) Conservation implications of invasion by plant hybridization. Biol Invasions 2:207-217. doi:10.1023/A:1010003603310

Weber E (1997) Morphological variation of the introduced perennial Solidago canadensis L. sensu lato (Asteraceae) in Europe. Bot J Linn Soc 123:197-210. doi:10.1111/j. 1095-8339.1997.tb01413.x

Zalewska-Gałosz J, Ronikier M (2012) Molecular evidence for two rare Potamogeton natans hybrids with reassessment of Potamogeton hybrid diversity in Poland. Aquat Bot 103:15-22. doi:10.1016/j.aquabot.2012.05.005

Zalewska-Gałosz J, Ronikier M, Kaplan Z (2010) Discovery of a new, recurrently formed Potamogeton hybrid in Europe and Africa: molecular evidence and morphological comparison of different clones. Taxon 59:559-566

Zalewska-Gałosz J, Jopek M, Ilnicki T (2014) Hybridisation in Batrachium group: controversial delimitation between heterophyllous Ranunculus penicillatus and the hybrid Ranunculus fluitans $\times R$. peltatus. Aquat Bot 120:160-168. doi:10.1016/j.aquabot.2014.03.002 